\title{
Turkish Validation Study of Caregiving Helplessness Questionnaire
}

\author{
Gizem Arikan', Asiye Kumru², Ali O. Ilhan ${ }^{3}$
}

Arikan, G., Kumru, A., \& Ilhan, A. O. (2021). Turkish validation study of Caregiving Helplessness Questionnaire. Nesne, 9(19), 52-68. DOI: 10.7816/nesne-09-19-05

Keywords
Caregiving,
helplessness,
mothers, parents,
psychometric
properties

Anahtar kelimeler Bakım, çaresizlik, anneler, ebeveynler, psikometrik özellikler

\begin{abstract}
Although various concepts focused on emotional difficulties of parents, helplessness in caregiving has not been addressed widely in the literature. Caregiving helplessness refers to feelings of loss of control and helplessness in child rearing. Thus, Solomon and George (2011) offered researchers and clinicians a tool to identify parents' helplessness feelings with developing Caregiving Helplessness Questionnaire (CHQ). Despite research on negative emotions about parenting with children suffering from specific health problems in Turkey, caregiving helplessness was not fully addressed by the researchers. In this study, we aimed to examine the validity and reliability of the CHQ in sample of 251 mothers (Mage=31; SD=5.00) with healthy toddlers (Mage=23 months; SD=6.90). The results pointed out a 2-factor solution for Turkish mothers, unlike 3-factor structure in the original scale. Mother Helpless and Mother-Child Frightened subscales came out as the first factor (Mh) and Child Caregiver subscale (Cc) as the second factor. Final CFA model (Model 3) demonstrated good model fit. CHQ's positive correlations with maternal symptoms (anxiety and depression) and child symptoms (internalization and externalization) indicated predictive validity similar to the original scale development study. CHQ also had acceptable internal consistency. We conclude that CHQ is a valid and reliable measure in Turkish sample which can be used in research, clinical and early intervention settings.
\end{abstract}

Farklı Karmașıklık Seviyelerine Sahip Sürüş Simülasyon Senaryoları Arasında Trafik İklimine Bağlı Farklılıklar

Öz

Alanyazında, ebeveynlerin karşılaştıkları duygusal zorlukların farklı şekillerde kavramlarla odaklanılsa da ebeveynlerin çaresizlik hissi geniş kapsamda incelenmemiştir. Çocuk bakımında çaresizlik çocuk yetiştirmeyle ilgili kontrolü kaybetme ve umutsuzluk duygusuyla tanımlanabilir. Bu tanımlamadan hareketle Solomon ve George (2011) Çocuk Bakımında Çaresizlik Ölçeğini (ÇBÇÖ) geliştirerek araştırmacılara ve klinisyenlere ebeveynlerin çaresizlik duygularını tespit edebilecekleri bir araç sunmuşlardır. Türkiye'deki araştırmalar çocuk bakımında çaresizlikten ziyade sağlık sorunu bulunan çocukların ebeveynlerinin olumsuz duyguları üzerinedir. Bu araştırmada, ÇBÇÖ'nün geçerlilik ve güvenilirliği sağlıklı ve erken çocukluk döneminde çocuğu olan (Ort Yaş=23 ay; SS=6.90) 251 annelerde incelenmiştir (Ort. Yaş=31; SS=5.00). Bulgular, ölçeğin aslındaki 3-boyutlu faktör yapısındansa 2boyutlu bir faktör yapısına işaret etmektedir. Anne çaresizliği ve anne-çocuk korkusu birinci faktör, bakım veren olarak çocuk ise ikinci faktör olarak karşımıza çıkmaktadır. Son olarak doğrulayıcı faktör analizi modeli (Model 3) iyi model uyumu göstermiştir. Asıl çalışmaya benzer şekilde ÇBÇÖ’nin anne belirtileri (kaygı ve depresyon) ve çocuk belirtileri (içselleştirme ve dışsallaştırma) ile pozitif korelasyon göstererek, ölçeğin yordayıcı geçerliliği sağladığı tespit edilmiştir. Ayrıca bulgular, ÇBÖÇÖ'nün kabul edilebilir bir iç tutarlılığa sahip olduğunu ortaya koymuştur. Sonuç olarak, ÇBÇÖ'nün Türkiye örnekleminde geçerli ve güvenilir bir ölçek olarak araştırma, klinik ve müdahale alanlarında kullanılabileceği gösterilmiştir.
Article History

Arrived: October 2, 2020

Revised: January 10, 2021

Accepted: February 17, 2021
Author Note:The study was supported by TUBITAK 3501 Carrier Program to the first author (No: 114K813.)

\footnotetext{
${ }^{1}$ Asst. Prof., Özyegin University, Department of Psychology, gizem.arikan(at)ozyegin.edu.tr, ORCID: 0000-0003-2961-6426

${ }^{2}$ Prof., Ozyegin University, Department of Psychology, asiye.kumru(at)ozyegin.edu.tr, ORCID: 0000-0002-1514-4248

${ }^{3}$ Asst. Prof, Ozyegin University, Department of Industrial Design, ali.ilhan(at)ozyegin.edu.tr, ORCID: 0000-0003-1850-9756
} 
Becoming a mother and raising a child mostly brings happiness and satisfaction to mothers. Motherhood, however, also changes women into caregivers while transforming their skills and abilities that can be linked to stress (George \& Solomon, 2008). Caregiving refers to a dyadic relationship (Weis, 1980) that is formed as a result of caregiver and caretaker behaviours. This is determined by biological underpinnings and their motivational control systems (George \& Solomon, 1996). Preserving life of an offspring is the main goal of a caregiver that leads to certain functions and behaviours (George \& Solomon, 2008). Hence, both internal and external signs of a caregiver, such as being apart from baby, child's stress and endangerment of child, are potent to trigger caregiving system leading to urge for care and soothing child (Solomon \& George, 2008). On the contrary, when the child is safe, nearby, satisfied, comforted, and well, deactivation of caregiving system takes place (George \& Solomon, 1996; Solomon \& George, 2008). Both activation and deactivation of the caregiving system are dependent on individual differences.

The most fundamental factors that linked with when and how caregiving system gets activated or deactivated can be the caregivers' own internal processes as well as their socioemotional characteristics. For example, parents can react differently to a minor playground accident in which a child falls off a swing. One parent can run screaming and grabbing the child. Another parent can calmly approach to the child help him/her standing while kindly checking if s/he is alright. Same incident can evoke extreme negative emotions in the first parent while the second parent does not perceive the event as alarming. This reflects both conscious and unconscious processing of the experience --here falling from a swing-- and upcoming information by the parent (Solomon \& George, 2008). Further, mothers' tendencies to respond in certain ways can reflect their own emotion regulation or dysregulation and their perceptions as well as feelings about their caregiving system goals (Solomon \& George, 2008; George \& Solomon, 2008). Thus, mothers can feel competent and happy about their overall caregiving or they may associate negative feelings to caregiving and experience helplessness.

In the literature, parenting related challenges conceptualised differently based on specific aspects, namely, parenting stress (Abidin, 1990), parental competence (Johnston \& Mash, 1989), parental expertise (Balling, 1995), parental efficacy beliefs (Fusterberg et al., 1999), parental burnout (Mikolajczak, et al., 2018a; Mikolajczak, et al., 2018b) parental self-efficacy (Ballenski \& Cook, 1982), and caregiving helplessness (Solomon \& George, 1996). Among all, specific difficulties of caregiving and psychological challenges such as helplessness encompass caregiving helplessness defined by Solomon and George (1996; 2008). However, there is limited number of studies concentrating on caregiving helplessness that identify variations among mothers based on individual differences (Collins \& Feeney, 2000; Feeney, 1996; George \& Solomon, 1996, 1989; Solomon \& George, 1996).

Helplessness is defined as the belief that nothing can be done to change an unwanted, adverse situation (Seligman, 1975). It is an extensively studied phenomenon in the educational science literature (Mark, 1983) in psychopathology (Pryce, et al., 2011; Swendensen, 1997; Wang, et al., 2017) and positive psychology (Farchi, et al., 2018; Maier \& Seligman, 2016), especially as learned helplessness. According to Abramson, Seligman and Teasdale (1978), a person feeling helpless in a situation learns that independent of whatever s/he does, adverse outcomes happen. Helplessness can be universal, in the sense that individual believes no one can do anything under the circumstances or can be personal linked with attributions (i.e., I cannot do anything) (Wallston, 2001).

Caregiving helplessness is associated with feeling out of control (George \& Solomon, 1989; 2008; 2011). Moreover, mothers with caregiving helplessness may also view their children as independent and not 
really in the need of care (George \& Solomon, 2011). Such a perspective is highly relevant because it can lead to disorganized caregiving and missing the "good enough care" standard (George \& Solomon, 2008). The disequilibrium in the caregiving system, which may disrupt the parent-child relationship, can develop when a mother experiences fear and helplessness (Solomon \& George, 2008).

The caregiving helplessness is based on two representations: dysregulation and constriction (George \& Solomon, 2008). Dysregulated mothers are prone to describe their children as out of control and have difficulty in relating themselves with their kids (George \& Solomon, 2008). On the other hand, constricted mothers view their children as independent and able to look after themselves on their own so they do not need to be protected and cared (George \& Solomon, 2008, 2011). These representations can be sourced from individual level problems (i.e., mother's psychological difficulties), and relational problems, disruptions dyadic interaction with their children.

At the individual level, one of the most highlighted factors affecting caregiving system is psychological well-being of mothers (George \& Solomon, 1996). Specifically, depressive symptoms play an important role in caregiving helplessness (Solomon \& George, 2011; Huth-Bocks, Guyon-Harris, Calvert, Scott, \& Ahlfs-Dunn, 2016). Moreover, in the study of Toz, Arikan and Ustundag-Budak (under review), maternal anxiety seems to contribute to caregiving helplessness more than depressive symptomatology in Turkish mothers. Supporting that finding, previous research also indicates maternal anxiety is an important risk factor for parenting, especially in the first years of child development (Seymour, Giallo, Cooklin \& Dunning, 2014). Post-natal maternal anxiety is related to less sensitive responses and reduced emotional tone within the mothers' interactions with infants (Nicol-Harper, Harvey \& Stein, 2007). It can be suggested that maternal caregiving helplessness can impact mother-child relationship leading to further problems in child's psychological well-being (i.e., experiencing internalization and externalization problems).

Parallel to research in the Western countries the critical role of feelings about caregiving and parenting are demonstrated in the studies on feelings of helplessness in Turkey (Toz, et al., under review) and parental burnout (Cüre, Üstündağ-Budak \& Arikan 2019). Caregiving helplessness is positively predicted by maternal anxiety and emotion regulation strategy of expressive suppression among mothers with toddlers (Toz, et al., under review). Moreover, low SES has an indirect effect via expressive suppression on caregiving helplessness. For certain emotion regulation strategies low SES and maternal anxiety can be the risk factors for mothers' feelings of helplessness in the early years of development. Parental burnout is also associated with toddler's externalization behavior problems indicating that negative feelings and exhaustion in relation to parenting can potentially impact parenthood, child-parent interaction, child's well-being (Cüre et al., 2019).

Based on the international and national findings, caregiving helplessness can be an important factor to understand parental difficulties and can eliminate them with effective intervention and prevention programs. Furthermore, mothers may undergo challenges in different phases of child' development and need to adjust themselves in relation to child's needs (Erikson, 1950; 1993) and other demands in their lives. Therefore, it is critical to differentiate caregiving helplessness due to its context specific nature indicating caregiver's disability and perceived inadequacy about providing care. However, there is no valid measure to use with Turkish sample. Thus, examining validity and reliability of Caregiving Helplessness Questionnaire (CHQ) developed by Solomon and George (2011) in a Turkish sample would fill this gap and facilitate further research in the field. 
The Caregiving Helplessness Questionnaire (George \& Solomon, 2011) has three subscales. These are Mother Helpless, Mother-Child Frightened, and Child Caregiver. The items of the questionnaire are derived from a 59-item pool, administered to 208 relatively high SES mothers with children between 3 and 11 years old in the US. In their study, caregiving interview helplessness ratings and helpless and frightened experiences of CHQ are positively correlated, indicating convergent validity. CHQ subscales and mothers' personal stress are not related that showing discriminant validity of CHQ. CHQ is positively associated with parenting stress, number of adverse attachment related events and maternal depression. Child externalization is positively related to helpless and frightened experiences which underlines the high risk group in quartile group comparison as well (George \& Solomon, 2011).

\section{Purpose of the Study}

Although CHQ taping on an influential phenomenon about parental negative outlook in relation to caregiving and can be used as a screening assessment by professionals in education, clinical and developmental psychology fields, reliability and validity of the questionnaire has not been tested in a Turkish sample yet. Previous research on caregiving helplessness mainly focused on the mothers coming from middle class and the responses of low SES parents have not been addressed in detail. Since earlier research demonstrates that low SES could be a critical risk factor for mothers in early years of development and is linked with caregiving helplessness (Toz, under review), we aimed to reach mothers with toddlers (13 years of age), who were coming from relatively low SES group. There were two aims of the present study, first to test the cultural equivalence of CHQ in terms of factor structure in Turkish setting based on George and Solomon (2011) findings. The second aim was to determine whether CHQ was a reliable and valid tool differentiating caregiving helplessness of mothers with toddlers who were coming from the low SES background.

\section{Method}

\section{Participants}

The study was announced and adverts distributed to pharmacies, community centers, kindergartens and in social media. In addition, undergraduate and graduate students were mobilized to disseminate the research information to mothers with toddlers. As a result, among 392 contacted mothers, 273 were eligible to participate the study. The participants $(N=251)$ who suffice the inclusion criteria of being healthy (not experiencing any severe health conditions) and having a healthy toddler at the age of between 1 and 3 years old were remained from 273 potential participants. Among 251 participants (Mage=31; SD=5.00; Range= $18-47$ years), $96 \%$ of the mothers were married. Their children's age ranged between 12 to 36 months ( $M=23$ months; $S D=6.90$ months). In terms of education level of the mothers: $13 \%$ had 2-year college degree $(n=32) ; 39 \%$ had high school diploma $(n=98) ; 25 \%$ was secondary school $(n=62)$ and $20 \%$ was primary school graduates $(n=51)$. Only, 3\% did not receive any formal education $(n=8)$. Household income distribution in percentages was as follows: $19 \%$ had 3001-5000TL, 48\% had 1501-3000TL, 31\% had 851$1500 \mathrm{TL}$ and $2 \%$ had $850 \mathrm{TL}$ and below. At the time of the study 4-member household poverty-line was 5000TL (TUIK, 2016). Seventy-two percent of the mothers looked after their children between 0-3 months on their own $(n=180)$ and $71 \%$ received support either from a family member, friend or close other. Mothers mostly remain sole caregivers with $69 \%$ between the 4-6 months of child $(n=174)$. Between 7-12 months, $60 \%$ of the mothers $(n=150)$ were sole caregiver and $40 \%$ received help. Between 12-18 months, 53\% of mothers were sole caregivers $(n=134)$ and $40 \%$ received support. Above 24 months $40 \%$ of the mothers 
$(n=85)$ looked after their children on their own while $60 \%$ of the mothers had help. For descriptive statistics see Table 1.

\section{Measurements}

Demographic Information Form: Mothers filled out a list of questions including their, age, marital status, occupational state, and financial and educational levels.

Caregiving Helplessness: Caregiving Helplessness Questionnaire (CHQ; Solomon \& George, 2011) consists of 25-items with a 5-point Likert Scale (1=Not Characteristic at All, 2=Somewhat Characteristic, 5=Very Characteristic) and 3 subscales, namely, mother helpless scale, mother-child frightened, and child caregiving. This questionnaire included 8 filler items in 26-items. Cronbach Alpha coefficients were as follows: .85 for Mother Helpless, .66 for Mother-Child Frightened, and .64 for Child Caregiving (Solomon $\&$ George, 2011). In the current study, Cronbach alpha values were .62 for child as caregiver; .87 for mother helplessness and mother-child frightened .87; and .84 for the total.

Depression and Anxiety: Brief Symptom Inventory (BSI; Derogatis, 1975, 1993) composed of 53-items with a 5-point Likert type ( $1=$ Never, $5=$ Always) inquiring psychological symptoms in the past 7 -days. The Turkish version adapted by Sahin and Dural (1994) and has five domains: Depression, Anxiety, Somatization, Hostility and Negative self. In the original study, the Cronbach's alpha was .85 for depression, and .66 for anxiety. The Cronbach's alphas for the Turkish version were .85 and .81 , respectively. In the present study, Cronbach alpha value for depression was .90 and for anxiety .91 .

Child Internalization and Externalization Behaviors: Child Behavior Checklist (CBCL; Achenbach, 1991; Achenbach \& Rescorla, 2000) was used to assess internalization and externalization behaviors. The scale consists of 113 questions, and 100 of them has 3-point Likert scale $(0=$ Not True, $2=$ Very True or Often True). Turkish version (Erol et al., 1995) was adapted by Erol and Simsek (1997) and had good psychometric properties. In our study, Cronbach's alpha values of the internalizing and externalizing subscales were as follows: .83 and .88 .

Table 1

Descriptive Statistics of Variables

\begin{tabular}{lllllllll}
\hline & Minimum & Maximum & M & SD & Skewness & Std. Error of Skewness & Kurtosis & Std. Error of Kurtosis \\
\hline CHQ Total & 1.06 & 4.5 & 2.27 & 0.65 & 0.77 & 0.15 & 0.61 & 0.31 \\
Cc & 1 & 5 & 3.10 & 0.78 & -0.04 & 0.15 & 0.02 & 0.31 \\
Mh & 1 & 4.67 & 2.10 & 0.68 & 0.99 & 0.15 & 0.79 & 0.31 \\
Depression & 0 & 3.67 & 0.95 & 0.82 & 1.04 & 0.15 & 0.34 & 0.31 \\
Anxiety & 0 & 3.62 & 0.70 & 0.74 & 1.58 & 0.15 & 2.38 & 0.31 \\
Internalizing & 0 & 1.62 & 0.37 & 0.24 & 0.80 & 0.15 & -0.03 & 0.31 \\
Externalizing & 0 & 1.58 & 0.52 & 0.36 & 0.55 & 0.15 & -0.59 & 0.31
\end{tabular}

Note: Cc (Child as caregiver subscale) and Mh (Mother helplessness and mother-child frightened subscale)

\section{Procedure}

The translation of CHQ was done by the first author of the manuscript and back translation was done by the second author and a family therapist. The questionnaire was checked by a psychologist and it was given to 3 parents to address any issues in the translation. After receiving the ethical approval from the university's board of ethics, we reached 251 mothers via adverts, announcements and undergrad and grad 
psychology students. The participants filled out a pack of questionnaire including a demographic form, CHQ, CBCL and BSI as well as other scales from a large scale project supported by TUBITAK 3501 Carrier Program to the first author (No: 114K813). The completion of the questionnaires took one hour and mothers a baby-diaper and booklet on play in early childhood were given to mothers as incentives.

\section{Data Analysis}

In order to examine the factor structure of the CHQ in Turkish cultural setting, first Principle Component Analysis (PCA) with Varimax rotation was conducted in Stata software (StataCorp., 2015). The factors with an Eigen value above one and explaining majority of the variance were determined. In addition, breaking points on Scree plots were also considered. Based on Cureton and D'Agostino (2013), .20 and above values in the item-loadings were taken into account. Also, item loadings to different factors were examined. Then, the confirmatory factor analysis (CFA) was performed again in Stata. To identify statistically valid models, model-fit indexes and Likelihood-ratio test using Chi-Square distribution were checked. The following model-fit indexes and values were taken as reference points: Comparative Fit Index (Bollen, 1989; Byrne, 1994), Root Mean Square Error of Approximation (RMSEA) (Kenny, 2015) and SRMR index (Hu \& Bentler, 1999) are accepted. Further, modification indexes were used to check if alterations in the model improve the model fit or not considering probably test.

To address the second aim of the study, we checked the associations of CHQ subscales with maternal depression, anxiety, and child internalization and externalization behavior reports of mothers for predictive validity purposes based on prior studies (George \& Solomon, 2011; Toz et al., under review). For testing internal consistency, we referred to Cronbach Alpha values of the subscales and total scale as well as Cronbach Alpha if item deleted values.

\section{Results}

We first examined the parameters in terms of factor solution considering Eigenvalue above 1 and Scree plot without filler items of 16, 19, 21, 22, 23, 24, 25 and 26 were examined. Eigenvalues for the first factor was 6.03 and for the second factor was 1.86. Scree plot depicted two breaking points and indicated that a 2-factor solution can be more likely. Therefore, we prioritized a 2-factor solution in PCA with Varimax rotation. The 2-factor solution revealed similar item distribution from the original scale in terms of child as caregiver $(\mathrm{Cc})$. But item distribution represented in 2-factor solution as mother helplessness and mother-child frightened items loaded on the same factor $(\mathrm{Mh})$ were both in line with theoretical framework and original factor structure (For factor loadings see Table 2.) The factor solution explained $42 \%$ of the variance.

In Stata, we further tested CHQ 2-factor solution in CFA (For Model Fit Statistics for 3 Models, See Table 3). In Model 1 (See Figure 1), modification indices suggested possible improvement with the error term correlations of item 18 and 20. In Model 2, item 18 and 20 correlated and compared to Model 1, Model 1 has a better fit $[\operatorname{LR} \chi 2(1)=43.55, p<.001]$. Further improvement was indicated in modification indices if item 11 and 17 error terms are correlated. Therefore, in Model 3 in which two items' error terms correlated was tested against Model 2 and demonstrated a better fit $[\operatorname{LR\chi } 2(1)=39.27, p<.001]$. Lastly, improvement was aimed by correlating the error terms of items 6 and 9 in Model 4 . However, Model 4 was not significantly better fit than Model $3[\operatorname{LR} \chi 2(1)=2.36, p=.125]$ and Model 3 was accepted as the final model for CHQ (See Figure 1 for unstandardized loadings of Model 1 and Model 3). 
Table 2

Caregiving Helplessness Questionnaire Items and Factor Loadings

Item numbers and Child Caregiving Helplessness Questionnaire

\begin{tabular}{|c|c|c|c|}
\hline & & \multicolumn{2}{|c|}{ Subscales } \\
\hline & & $\mathrm{Mh}$ & $\mathrm{Cc}$ \\
\hline 1. & When I am with my child, I often feel out of control. & .28 & .03 \\
\hline 2. & My child is good at tending to and caring for others & -.07 & .45 \\
\hline 3. & I am frightened of my child. & .26 & .06 \\
\hline 4. & My child hits, kicks, or bites me. & .26 & .02 \\
\hline 5. & I often feel that there is nothing I can do to discipline my child. & .25 & -.03 \\
\hline 6. & My child knows how to put other people at ease. & .01 & .44 \\
\hline 7. & When I am with my child, I often feel that my child is out of control. & .28 & .02 \\
\hline 8. & I feel that my child is a great actor/actress. & .23 & .13 \\
\hline 9. & My child is very sensitive to the feelings and needs of others. & -.02 & .47 \\
\hline 10. & I feel that I am a failure as a mother. & .27 & .06 \\
\hline 11. & My child likes to be a clown or family comedian. & .06 & .37 \\
\hline 12. & I feel that I punish my child more harshly than I should. & .29 & .06 \\
\hline 13. & My child becomes so upset or distressed that he can't be soothed. & .31 & -.08 \\
\hline 14. & My child loses it when he/she is separated from me. & .24 & -.08 \\
\hline 15. & Sometimes my child acts as if he/she is afraid of me. & .28 & .04 \\
\hline 16. & I enjoy doing things with my child that make him or her happy. * & & \\
\hline 17. & My child is always trying to make others laugh. & .05 & .40 \\
\hline 18. & $\begin{array}{l}\text { I feel that my situation needs to be changed but am helpless } \\
\text { to do anything about it. }\end{array}$ & .31 & -.07 \\
\hline 19. & I would describe myself as a reliable person. * & & \\
\hline 20. & I feel that my life is chaotic and out of control & .30 & -.05 \\
\hline 21. & I am rarely bored when I am with my child.* & & \\
\hline 22. & My child treats me in a rude or sarcastic way.* & & \\
\hline 23. & I am happy with myself just the way I am.* & & \\
\hline 24. & I rarely feel guilty about my actions.* & & \\
\hline 25. & I can easily express myself to others.* & & \\
\hline 26. & I frequently talk to others about my child.* & & \\
\hline
\end{tabular}

To test psychometric properties of CHQ, Cronbach Alpha values and Cronbach alpha if item deleted values were examined. The Cronbach alpha values were as follows: For child as caregiver .62; for mother helplessness and mother-child frightened .87; and for the total .84. Also, predictive validity was checked by Pearson correlation coefficient values (See Table 4). We found that Cc was positively associated with Mh, child's internalization and age. Furthermore, Mh was positively associated with depression, anxiety, child's age and both internalization and externalization. CHQ total score demonstrated similar correlations as in Mh subscale. 

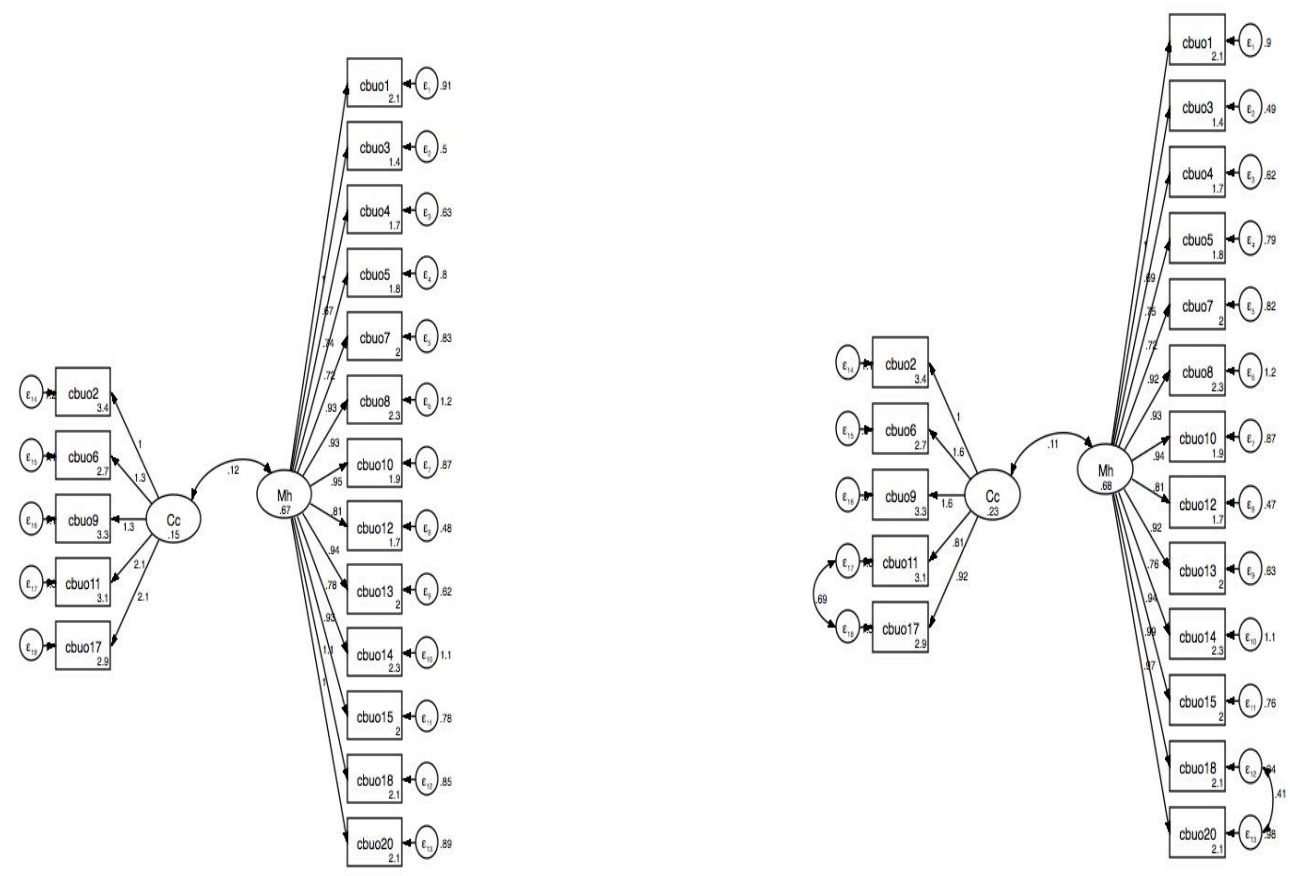

Figure 1. Caregiving Helplessness Questionnaire Confirmatory Factor Analysis Unstandardized Values in Model 1 and Final Model 3 Note: Cc (Child as caregiver subscale) and Mh (Mother helplessness and mother-child frightened subscale)

\section{Table 3}

Model Fit Statistics

\begin{tabular}{|c|c|c|c|c|}
\hline Model & $\chi^{2}(\mathrm{df})$ & & & SRMR \\
\hline 1 & $353.32(134)$ & .85 & .08 & .06 \\
\hline 2 & 309.78 (133) & .88 & .07 & .06 \\
\hline 3 & $270.51(132)$ & .90 & .06 & .06 \\
\hline
\end{tabular}


Table 4

Pearson Correlation Coefficients of Caregiving Helplessness Questionnaire with Demographic and Other Factors for Predictive Validity

\begin{tabular}{|c|c|c|c|c|c|c|c|c|c|c|c|}
\hline & 2 & 3 & 4 & 5 & 6 & 7 & 8 & 9 & 10 & 11 & 12 \\
\hline 1. Child sex & -.04 & .04 & -.09 & $<.01$ & -.08 & .03 & $<.01$ & .05 & .05 & .02 & $.15^{*}$ \\
\hline 2. Child age & - & .08 & -.07 & -.01 & .04 & $.15^{*}$ & $.15 *$ & .03 & .05 & .07 & $.13 *$ \\
\hline 3. Mother age & & - & -.04 & $.13 *$ & -.01 & -.10 & -.08 & -.05 & -.05 & -.06 & -.01 \\
\hline 4. Mother edu & & & - & $.53 * *$ & -.09 & -.08 & -.10 & -.09 & -.16 & $-.15^{*}$ & -.11 \\
\hline 5. Income & & & & - & -.04 & -.03 & -.05 & -.10 & -.10 & $-.17 * *$ & -.01 \\
\hline 6. $\mathrm{Cc}$ & & & & & - & $.30 * *$ & $.60 * *$ & .11 & .11 & $.16^{* *}$ & .11 \\
\hline 7. Mh & & & & & & - & $.93 * *$ & $.19 * *$ & $.24 * *$ & $.35^{* *}$ & $.35 * *$ \\
\hline 8. CH Total & & & & & & & - & $.29 * *$ & $.33 * *$ & $.38 * *$ & $.37 * *$ \\
\hline $\begin{array}{l}\text { 9. Mother } \\
\text { depression }\end{array}$ & & & & & & & & - & $.86 * *$ & $.50 * *$ & $.56 * *$ \\
\hline 10. Mother anxiety & & & & & & & & & - & $.55^{* *}$ & $.56 * *$ \\
\hline $\begin{array}{l}\text { 11. Child } \\
\text { internalization } \\
\text { 12. Child } \\
\text { externalization }\end{array}$ & & & & & & & & & & - & $\begin{array}{l}.62 * * \\
-\end{array}$ \\
\hline
\end{tabular}

\section{Discussion}

The main aim of the study was to test cultural equivalence and psychometric properties of CHQ in a sample of Turkish mothers with toddlers. Our findings revealed that unlike the US sample, rather than 3factor solution of Solomon and George (2011), namely, Mother Helpless, Mother-Child Frightened, and Child Caregiver, a 2-factor structure was yielded both based on Scree plot and PCA. In our sample, the Mother Helpless and Mother-Child Frightened scales' items loaded on the same factor, and Child Caregiving revealed as a separate factor. In the US sample, Mother Helpless and Mother-Child Frightened subscales were positively correlated. Whereas, Mother Helpless and Child Caregiving were not related with each other. Mother-Child Frightened and Child Caregiving were positively associated. In the Turkish sample Child Caregiving scale was moderately correlated with Mh factor containing both Mother Helpless scale and Mother-Child Frightened scale's items.

When items are examined, Mh subscale items were representing both emotional difficulties in the context of relationship and negative attributions about self as a mother and child. This subscale was different from Child Caregiving scale because it did not concentrate solely on child and his/her specific behaviors as well as characteristics. In our study, Child Caregiving came out as a separate factor but Mother Helpless and Mother-Child Frightened subscales revealed as one factor. It was not substantially opposite to the Solomon and George (2011) validation study because these two subscales were correlated (.58), which may come up with loading on to same factor in our study.

As stated in the validation study of Solomon and George (2011), Mother Helpless subscale signified the disorganized caregiving and indicated predominantly caregiving problems. Similarly, in our study, revealing as one uniform factor-Mother Helpless and Mother Child Frightened combined (Mh) subscaledemonstrates relevance of this domain in caregiving helplessness. Further, evidence from intervention 
research also showed that Mother-child frightening experiences and maternal helplessness can complement each other since they were related. Schechter et al. (2006) showed that reducing traumatized mothers' erroneous perceptions and cognitions in mother-child relationship lowered maternal feelings of helplessness. In our study, loading on the same factor can indicate such a relationship between two domains of CHQ and their importance for examining maternal caregiving helplessness.

The emotions and behaviors that parents demonstrate in the context of parenting can reflect their culture (Harkness \& Super, 2002). We know that parents in collectivist and individualist cultures can be different in the way that they make attributions about their children, which can also be observed by their parenting practices (Harkness \& Super, 1992; Harwood, Schoelmerich, Schulze, \& Gonzalez, 1999) and how they feel about caregiving. In Turkey, social expectations with the influence of collectivism (Ozutku \& Altindis, 2013) and sacred place of motherhood in Turkish culture can impact mothers' perceptions and attributions about their children and the way they feel about caregiving. For example, they do not report parental burnout as much as in other cultures (Roskam, et. al., 2019). Moreover, norms, experiences, feelings about parenting (Arikan, et al., under review; Arikan \& Kumru, 2020), and caregiving (Toz, et al., under review) can be related to both psychological state of the parents and their children in Turkey (Cüre, et al., 2019). Our findings suggest that when dealing with adaptation of any measure, it is important to check cultural equivalence.

When psychometric properties examined, our findings revealed that internal consistency of CHQ subscales was parallel to the original validation study of Solomon and George (2011). That is, the mother helplessness and mother-child frightened subscale's internal consistency was high but the child caregiver (Cc) scale was low similar to Solomon and George (2011). The reason for low Cronbach alpha for Cc scale in both Turkish and US cultural contexts could possibly indicate mothers' inconsistent perceptions about their children. During toddlerhood, it can be hard for mothers to rate some of the Cc items (i.e., My child is good attending to and caring for others) because these characteristics can be hardly observed in early childhood unlike Mother-child Frightened scale which demonstrates dysregulated caregiving representations involving high conflict and lack of control (George \& Solomon, 2008; Solomon \& George, 2011). When items of the Cc subscale examined, child's negative qualities are dominant.

When predictive validity of the subscales was examined, our results showed that there were positive correlations between maternal symptoms of depression and anxiety, and total score of CHQ. These findings provided evidence for the predictive validity of CHQ total score. However, the subscales of the CHQ demonstrated slight differences in the predictive validity. Specifically, Mh subscale was related to maternal depression and anxiety but Cc subscale was not. In other words, mother's feelings and the way she is related to her child are also associated with her psychological difficulties.

With regard to child problem behaviours, CHQ total score and Mh subscale exhibited positive correlations revealing predictive validity of the CHQ and Mh. However, Cc subscale was only positively related with child internalization but not with externalization. In the original scale validation study of Solomon and George (2011), only child externalization was positively associated with Mother-child Frightened and Mother Helpless subscales. There was no association between CHQ subscales and child internalization. According to Solomon and George (2011) Cc scale is concentrated on extreme people pleasing characteristics of a child, in other words, "angel child". It can be expected that such children may exhibit more withdrawing, depressed and anxious mood that can form internalization behaviors. Therefore, mothers may have responded both Cc scale and internalization items highly. 
Contrary to our expectations, none of the subscales were related to income or mother's education level, suggesting that regardless of SES mothers can experience caregiving helplessness. These listed associations during toddlerhood can be critical to facilitate effective interventions which can be established only by understanding individual differences in parenting and caregiving problems of parents. Although literature on parenting challenges such as parental stress (Arikan, Kumru, Korkut \& Ilhan, 2019; Akkok, Aşkak \& Karanci, 1992; Özmen-Kaymak-Özmen, 2012; Çekiç \& Hamamci, 2018) and parental burnout (Ardıç \& Olcay, 2019; Arikan et al., under review), these studies do not fully capture parents' negative feelings and cognitions about caregiving. This study filled that gap by providing a new validated measure for the researchers, who can disentangle complex nature of caregiving in the Turkish cultural context. Besides there were other important findings that could have further implications for researchers and professionals.

Our results did not only demonstrate that CHQ total is a reliable and valid tool to examine maternal helplessness in relation to caregiving but we also revealed maternal depression and anxiety as well as child early problem behaviors can be related to maternal caregiving helplessness. This can pave the way to investigate caregiving helplessness as a risk factor for maternal sensitivity and effective caregiving during toddlerhood. Still, the low internal consistency and low predictive validity of Cc scale should be explored in future studies.

Finally, as both our results and earlier research (Solomon \& George, 2011) indicate caregiving helplessness can be a fundamental issue for parents especially the disadvantaged groups such as low socioeconomic status and with health conditions. Specific factors that can potentially empower mothers' caregiving efficacy and reduce helplessness feelings should be addressed in further research. As short and long term effects of caregiving helplessness may impact child's life, this area of research deserves further attention for designing interventions focusing on different phases of child development. In addition, caregiving helplessness can be observed in fathers and other family members taking care of elderly. As a result, CHQ can be altered and used for other relationship contexts. Especially, with current developments during COVID-19, parents' helplessness feelings need to be explored to assist them effectively in the future.

\section{References}

Abidin, R. R. (1990). Parenting Stress Index Manual. IDLEWOOD Drive, Charlottesville: Pediatric Psychology Press.

Abramson, L. Y. (1978). Learned helplessness in humans: critique and reformulation. Journal of Abnormal Psychology, 87, 49-74. https://www.doi.org/10.1037/0021-843X.87.1.49

Achenbach, T. M. (1991). Manual for the Child Behavior Checklist/4-18 and 1991 profile. University of Vermont, Department of Psychiatry.

Achenbach, T. M., \& Rescorla, L. A. (2000). Child behavior checklist for ages 1 1/2-5. ASEBA. University of Vermont.

Achenbach, T. M., \& Rescorla, L. A. (2000). Manual for the ASEBA preschool forms and profiles (Vol. 30). Burlington, VT: University of Vermont, Research center for children, youth, \& families.

Ardıç, A., \& Olçay, S. (2019). Anne-Baba Tükenmişlik Ölçeği'nin psikometrik özelliklerinin belirlenmesi. Inonu University Journal of the Faculty of Education (INUJFE), 20(2), 619-632. http://www.doi.org/10.17679/inuefd.531692

Avşar, A. \& Olçay, S. (2019). Determination of psychometric properties of the parents burnout scale. Inonu University Journal of the Faculty of Education, 20(2), 619-632. https://www.doi.org/10.17679/inuefd.531692 
Arikan, G., A. Kumru., Korkut, B., \& Ilhan, A. O. (2019). Examining toddlers' problem behaviors: The role of SES, parenting stress, perceived support, and negative intentionality. Journal of Child \& Family Studies, 28, 3467-3478. https://doi.org/10.1007/s10826-019-01529-y

Arikan, G., Ustundag-Budak, A. M., Akgün, E., Mikolajczak, M. \& Roskam, I. (under review). Validation of Turkish version of the Parental Burnout Assessment (PBA).

Arikan, G. \& Kumru, A. (2020). Pattern of associations between maternal symptoms and child problem behaviors: The mediating role of mentalization, negative intentionality, and unsupportive emotion socialization. Child Psychiatry and Human Development. https://www.doi.org/10.1007/s10578-02001046-w

Akkok, F , Aşkak, P , Karancı, A . (1992). Özürlü bir çocuğa sahip anne - babalardaki stresin yordanması. Özel Ë̆itim Dergisi, 1(2), 8-12.

Ballenski, C. B., \& Cook, A. S. (1982). Mothers perceptions of their competence in managing selected parenting tasks. Family Relations, 31, 489. https://doi.org/10.2307/583923

Balling, K. (1995). Valuing of parental expertise scale. Unpublished scale. University of WisconsinMadison, Madison, Wisconsin.

Bollen, K. A. (1989). Structural equations with latent variables. NY: Wiley.

Byrne, B. M. (1994). Structural equation modeling with EQS and EQS/Windows: Basic concepts, applications, and programming. Sage Publications.

Collins, N. L., \& Feeney, B. C. (2000). A safe haven: An attachment theory perspective on support seeking and caregiving in intimate relationships. Journal of Personality and Social Psychology, 78(6), 10531073. https://www.doi.org/10.1O37//OO22-3514.78.6.1053

Cüre S., Üstündağ-Budak, A.M. \& Arikan G. (2019, December). Does Parental Alexithymia Predicts Parental Burnout and Child Psychological Problems? Paper presented at the International Investigation of Parental Burnout (IIPB) Conference, UCLouvain, Belgium.

Cureton, E. E., \& D'Agostino, R. B. (2013). Factor analysis: An applied approach. Psychology press.

Çekiç, A., \& Hamamci, Z. (2018). Anne-Baba Stres Ölçeği Kısa Formunun Türkçe’ye uyarlanması: Geçerlilik ve güvenilirlik çalışması. Anatolian Journal of Psychiatry/Anadolu Psikiyatri Dergisi, 19(1).https://www.doi.org/10.5455/apd.263093

Derogatis, L. R. (1975). Brief symptom inventory, clinical psychometric research. Baltimore, MD: Clinical Psychometric Research.

Derogatis, L. R., \& Spencer, P. M. (1993). Brief symptom inventory: BSI (Vol. 18). Upper Saddle River, NJ: Pearson.

Erikson, E. (1950). Childhood and Society. New York: Norton.

Erikson, E. (1993). Childhood and society. New York: Norton.

Erol, N., Bengi-Arslan, L., \& Akçakın, M. (1995). The adaptation and standardization of the Child Behavioral Checklist among 6- to 18-year-old Turkish children. In J. Sergeant (Ed). Eunethydis: European Approaches to Hyperkinetic Disorder (pp. 97-113). Zurich, Switzerland: Fotorotar.

Erol, N., \& Simsek, Z. (1997). Mental health profiles of Turkey: Behavioral/emotional problems and competencies in Turkish children. Mental health profiles of Turkey: A preliminary report, 12-33.

Farchi, M., Levy, T. B., Gershon, B. B., Hirsch-Gornemann, M. B., Whiteson, A., \& Gidron, Y. (2018). The SIX Cs model for immediate cognitive psychological first aid: From helplessness to active efficient coping. International Journal of Emergency Mental Health and Human Resilience, 20(2), 1-12.

Feeney, J. A. (1996). Attachment, caregiving, and marital satisfaction. Personal Relationships, 3(4), 401416. https://www.doi.org/10.1111/j.1475-6811.1996.tb00124.x

Furstenberg, F., Cook, T. D., Eccles, J., Elder, G., \& Sameroff, A. (1999). Managing to make it: Urban families and adolescent success. Chicago, IL: The University of Chicago Press Ltd. 
George, C. \& Solomon, J. (2008). The caregiving system: A behavioral systems approach to parenting. In J. Cassidy \& P. R. Shaver (Eds.), Handbook of attachment: Theory, research, and clinical applications (2nd ed., pp. 833-856). New York, NY: Guilford Press.

George, C. \& Solomon, J. (1996). Representational models of relationships: Links between caregiving and attachment. Infant Mental Health Journal, 17(3), 198-216.

George, C. \& Solomon, J. (1989). Internal working models of caregiving and security of attachment at age six. Infant Mental Health Journal, 10(3), 222-237.

George, C. \& Solomon, J. (2011). Caregiving Helplessness: The Development of a Screening Measure for Disorganized Maternal Caregiving. In J. Solomon \& C. George (Eds.), Disorganized attachment and caregiving (pp. 133-166). New York, NY, US: Guilford Press.

Harkness, S., \& Super, C. M. (2002). Culture and parenting. In M. H. Bornstein (Ed.), Handbook of parenting, Vol. 2: Biology and ecology of parenting (2nd ed., pp. 253-280). Mahwah, NJ: Lawrence Erlbaum.

Harkness, S., \& Super, C. M. (1995). Culture and parenting. In M. H. Bornstein (Ed.), Handbook of parenting, Vol. 2. Biology and ecology of parenting (p. 211-234). Lawrence Erlbaum Associates, Inc.

Harwood, R. L., Schoelmerich, A., Schulze, P. A., \& Gonzalez, Z. (1999). Cultural differences in maternal beliefs and behaviors: A study of middle-class Anglo and Puerto Rican mother-infant pairs in four everyday situations. Child Development, 70(4), 1005-1016. https://www.doi.org/10.1111/14678624.00073

Hu, L. T., \& Bentler, P. M. (1999). Cutoff criteria for fit indexes in covariance structure analysis: Conventional criteria versus new alternatives. Structural Equation Modeling: A Multidisciplinary Journal, 6(1), 1-55. https://www.doi.org/10.1080/10705519909540118

Huth-Bocks, A.C., Guyon-Harris, K., Calvert, M., Scott, S., \& Ahlfs-Dunn, S. (2016). The Caregiving Helplessness Questionnaire: Evidence for validity and utility with mothers of infants. Infant Mental Health Journal, 37(3), 208-221. https://www.doi.org/10.1002/imhj.21559

Johnston, C., \& Mash, E. J. (1989). A measure of parenting satisfaction and efficacy. Journal of Clinical Child Psychology, 18(2), 167-175. https://www.doi.org/10.1207/s15374424jccp1802_8

Kaymak-Özmen, S., \& Özmen, A. (2012). Anne baba stres ölçeğinin geliştirilmesi. Milli Eğitim Dergisi, 42(196), 20-35.

Kenny, D. A. (2015). Measuring Model Fit. Retrieved from: http://davidakenny.net/cm/fit.htm

Maier, S. F., \& Seligman, M. E. (2016). Learned helplessness at fifty: Insights from neuroscience. Psychological Review, 123(4), 349. https://www.doi.org/10.1037/rev0000033

Mark, S. F. (1983). To succeed or not to succeed: A critical review of issues in learned helplessness. Contemporary Educational Psychology, 8(1), 1-19. https://www.doi.org/ 10.1016/0361476X(83)90030-9

Mikolajczak, M., Brianda, M. E., Avalosse, H., and Roskam, I. (2018a). Consequences of parental burnout: Its specific effect on child neglect and violence. Child Abuse \& Neglect. 80, 134-145. https://www.doi.org/10.1016/j.chiabu.2018.03.025.

Mikolajczak, M., Raes, M.-E., Avalosse, H., and Roskam, I. (2018b). Exhausted parents: sociodemographic, child-related, parent-related, parenting and family functioning correlates of parental burnout. Journal of Child and Family Studies, 27, 602-614. https://www.doi.org/10.1007/s10826-017-0892-4.

Nicol-Harper, R., Harvey, A. G., \& Stein, A. (2007). Interactions between mothers and infants: Impact of maternal anxiety. Infant Behavior \& Development, 30(1), 161-167. https://www.doi.org/10.1016/j.infbeh.2006.08.005 
Ozutku, H., \& Altindis, S. (2013). The relations between work intensity and work-family conflict in collectivist culture: Evidence from Turkish health care professionals. Journal of Health Management, 15(3), 361-382. https://www.doi.org/10.1177/0972063413492049

Pryce, C. R., Azzinnari, D., Spinelli, S., Seifritz, E., Tegethoff, M., \& Meinlschmidt, G. (2011). Helplessness: a systematic translational review of theory and evidence for its relevance to understanding and treating depression. Pharmacology \& Therapeutics, 132(3), 242-267. https://www.doi.org/10.1016/j.pharmthera.2011.06.006

Roskam, I. \& Mikolajczak, M. (2019, December). Exciting findings from International investigation of Parental Burnout. 1st Parental Burnout Conference, Belgium, Louvain-la-Neuve.

Sahin, N. H., \& Durak, A. (1994). Kisa Semptom Envanteri (Brief Symptom Invetory-BSI): Turk gençleri için uyarlanması [A study of the Brief Symptom Inventory in Turkish youth]. Türk Psikoloji Dergisi, 9(31), 44-56.

Schechter, D. S., Myers, M. M., Brunelli, S. A., Coates, S. W., Zeanah, Jr, C. H., Davies, M., ... Liebowitz, M. R. (2006). Traumatized mothers can change their minds about their toddlers: Understanding how a novel use of video feedback supports positive change of maternal attributions. Infant Mental Health 27(5), 429-447. https://www.doi.org/10.1002/imhj.20101

Seligman, M. E. (1975). Helplessness: On depression, development, and death. Friedman, San Francisco.

Seymour, M., Giallo, R., Cooklin, A., \& Dunning, M. (2015). Maternal anxiety, risk factors and parenting in the first post-natal year. Child: Care, Health \& Development, 41(2), 314-323. DOI: $10.1111 /$ cch. 12178

Solomon, J., \& George, C. (1996). Defining the caregiving system: Toward a theory of caregiving. Infant Mental Health, 17, 183-197.

Solomon, J., \& George, C. (2008). The measurement of attachment security and related constructs in infancy and early childhood. In J. Cassidy \& P. R. Shaver (Eds.), Handbook of attachment: Theory, research, and clinical applications (pp. 383-416). New York, NY: Guilford Press.

Solomon, J. \& George, C. (Eds.). (2011). Disorganized attachment and caregiving. New York, NY: Guilford Press.

StataCorp. (2017). Stata Statistical Software: Release 15. College Station, TX: StataCorp LLC.

Swendsen, J. D. (1997). Anxiety, Depression, and Their Comorbidity: An Experience Sampling Test of the Helplessness-Hopelessness Theory. Cognitive Therapy and Research, 21(1), 97. https://www.doi.org/10.1023/a:1021872410824

Toz, N., Arikan, G. \& Ustundag-Budak A. M. (Under review). The Role of Emotion Regulation and Maternal Symptoms in Caregiving Helplessness during Toddlerhood Years.

Turkish Statistical Institute (2016) Report. Retrieved from: www.tuik.gov.tr/UstMenu.do?metod=temelist on May 2019

Wallston, K.A. (2001). Control beliefs: Health Perspectives. In N. J. Smelser \& P. B. Baltes (Eds.), International encyclopedia of the social and behavioral sciences. Oxford, UK: Elsevier Science.

Wang, C. Y., Zhang, K., \& Zhang, M. (2017). Dysfunctional attitudes, learned helplessness, and coping styles among men with substance use disorders. Social Behavior and Personality: An International Journal, 45(2), 269-280. https://doi.org/10.2224/sbp.5825

Weiss, R. L. (1980). Strategic behavioral marital therapy: Toward a model for assessment and intervention. In J. P. Vincent (Ed.). Advances in family intervention, assessment and theory (Vol. 1, pp. 229-271). Greenwich, CT: JAI Press. 


\section{UZUN ÖZET}

\section{Çocuk Bakımında Çaresizlik Ölçeği Türkiye Geçerlik Çalışması}

Çocuk sahibi olmak ve annelik genel olarak büyük bir mutluluk ve doyum kaynağı olmakla beraber büyük değişimleri de beraberinde getirerek, kişide olumsuz duygular ve stres yaratabilir (George ve Solomon, 2008). Çocuğun ihtiyaçlarını karşılarken, onun durumunu ve beklentilerini değerlendirebilmek önemlidir (George ve Solomon, 1996). Bakım verme sistemi çocuğun sinyalleriyle aktif hale geldiğinde, ebeveyn çocuğun ihtiyaçlarını fark edebilir ve bunlara yönelik davranışlarda bulunabilir (George ve Solomon, 1996; Solomon ve George, 2008). Ancak bu sistemin aktif veya pasif halde olması farkl1 faktörlerle şekillenebildiği gibi, annelerin bireysel farklılıkları da etkili olabilir (Örn. kişilik özellikleri) (George ve Solomon, 1996; Solomon ve George, 2008). Bu kapsamda çocuklara bakım verenler, genelde de anneler, bazı olumsuz duygular yaşayabilirler. Alanyazında ebeveynlerin yaşadığı bu olumsuz duygular farklı kavramlarla incelenmiştir. Örneğin ebeveynlik stresi (Abidin, 1990), ebeveyn yeterliliği (Johnston ve Mash, 1989), ebeveyn yetkinliği (Balling, 1995), ebeveyn yetebilirlik duyguları (Fusterberg, vd., 1999), ebeveyn tükenmişliği (Mikolajczak, vd., 2018a; Mikolajczak, vd., 2018b) ve çocuk bakımında çaresizlik (Solomon ve George, 1996) yaygın kullanılan kavramlar arasındadır.

Çocuk bakımında çaresizlik, bakım veren kişinin kontrolü kaybetme hissiyle gelişen duygu olarak tanımlanmaktadır (George ve Solomon, 1989; 2008; 2011). Bu duygunun gelişmesiyle, anne çocuğun bakıma ve desteğe ihtiyacı olmadığı algısını edinirbilir ve "yeterince iyi” anne olmada sıkıntılar yaşayabilir (George ve Solomon, 2008). Bu dengesizlik haline, yoğun korku hissi de eşlik edebilir ve annenin çocukla ilgili algısını, atıflarını, davranışlarını olumsuz etkileyebilir (George ve Solomon, 2008). Yapılan araştırmalardaki bulgular, çocuk bakımında çaresizlik ile annenin depresif duygu durumu (Solomon ve George, 2011; Huth-Bocks, Guyon-Harris, Calvert, Scott, ve Ahlfs-Dunn, 2016) ve kaygis1 (Toz vd., değerlendirmede) arasında pozitif bir ilişki olduğuna işaret etmektedir. Ancak ülkemizde çocuk bakımındaki zorluklara yönelik araştırmalar sınırlıdır (Cüre vd., 2019; Toz vd., değerlendirmede) ve bu alandaki ölçekler yetersizdir. Bu bağlamda araştırmanın amacı, erken dönemde sağlıklı çocukları olan annelerde Çocuk Bakımında Çaresizlik Ölçeği (ÇBÇÖ)'nin, geçerlik ve güvenirliğini test etmek ve psikometrik özelliklerini incelemektir.

\section{Yöntem}

Çalışmamızda 392 anne ile iletişim kurulmuş ve bu anneler arasından 273 anne katılabileceğini belirtmiştir. Araştırmaya dahil olma ölçütü 1-3 yaş arasında çocuk sahibi olmak ve hem annenin hem de çocuğunun sağlıklı olmasıdır. Bu ölçütler dikkate alındığında 251 anne (OrtYaş=31; SS=5.00; Ranj=18-47 yıl) anketleri doldurmuştur. Annelerin \%96'sı evli ve çocukları 12 ile 36 ay arasındadır (OrtYaş = 23ay; SS=6.90 ay). Annelerin \%13'ü 2-ylllı yüksekokul, \%39'u lise, \%25'i ortaokul, \%20'si ilkokul mezunu ve \%3'ü ise formal eğitim almamıştır. Katılımcıların \%19'u 3001-5000TL, \%48'i 1501-3000TL, \%31'i 851$1500 \mathrm{TL}$ ve \%2'si 850TL altı gelir bildirmiştir. Araştırmanın başladığı tarihte 2 çocuklu bir aile için yoksulluk sınırı yaklaşık 5000TL olarak tespit edilmiştir (TUIK, 2016). Katılımcılar demografik bilgi formuyla yaş, eğitim, gelir, medeni hal ve çalışma durumu gibi sorularla birlikte, ÇBÇÖ (Solomon ve George, 2011), Kısa Semptom Envanteri (Derogatis, 1975, 1993) ve Çocuk Davranış Listesi'ni (Achenbach, 1991; Achenbach ve Rescorla, 2000) doldurmuşlardır. Araştırmadaki değişkenlere göre Cronbach Alpha iç güvenilirlik katsayıları şöyledir: Kısa Semptom Envanteri depresyon alt ölçeği için .90; kaygı alt ölçeği için 
.91; çocuk davranış listesi içselleştirme davranışları alt ölçeği için .83 ve dışsallaştırma alt ölçeği için .88. ÇBÇÖ için ise anne çaresizliği ve anne-çocuk korkusu alt ölçeği .87; bakım veren olarak çocuk alt ölçeği .62 ve total ölçek .84'tür.

\section{Sonuç ve Tartışma}

Betimleyici Faktör Analiziyle olası iki faktörlü model, STATA (2015) kullanılarak yapılan Doğrulayıc1 Faktör Analizi (DFA)ile alan yazında önerilen indeks değerleri dikkate alınarak incelenmiştir. Bunlar CFI indeksi (Bollen, 1989); RMSEA değeri (Kenny, 2015) ve SRMR endeksidir (Hu ve Bentler, 1999). Test edilen ilk model istatistiksel olarak anlamlı olmakla beraber $[\chi 2(134)=353.32, \mathrm{CFI}=.85$, RMSEA $=.08$, SRMR $=.06$ ] 18. ve 20. maddelerin hata değerlerinin ilişkilendirilerek daha iyi hale getirilebileceğine işaret etmiştir. Bu düzenleme yapıldıktan sonraki ikinci modelin $[\chi 2(133)=309.78, \mathrm{CFI}=$ .88 , RMSEA = .07, SRMR =.06] istatistiksel olarak anlamlı şekilde üstün olduğu tespit edilmiştir [LR $\chi 2(1)$ $=43.55, \mathrm{p}<.001]$. Bu modeldeki 11. ve 17. maddelerin hata değerlerinin ilişkilendirilmesiyle elde edilen 3 . model $[\chi 2(132)=270.51, \mathrm{CFI}=.90, \mathrm{RMSEA}=.06$, SRMR $=.06] 2$. modele göre istatistiksel olarak üstündür [LR $\chi 2(1)=39.27, \mathrm{p}<.001]$. Son olarak 6. ve 9. maddelerin hata değerlerinin ilişkilendirilmesiyle elde edilen 4. model ile 3.model kıyaslanmış ve istatistiksel olarak 4. modelin 3. modelden üstün olmadığ1 saptanmıştır $[\operatorname{LR} \chi 2(1)=2.36, p=.125]$. Ölçeğin güvenilirlik katsayıları şu şekildedir: Anne çaresizliği ve anne-çocuk korkusu alt ölçeği için .87; bakım veren olarak çocuk alt ölçeği için .62 ve toplam ölçek için .84. Yordayıcı geçerlik kapsamında yapılan analizlerde, anne çaresizliği ve anne-çocuk korkusu alt ölçeğinin annenin depresyonu, kaygısı, çocuğun yaşı ve çocuğun içselleştirme ve dışsallaştırma davranışları ile pozitif ilişkide olduğu görülmüştür. Bakım veren olarak çocuk alt ölçeği ise içselleştirme ve çocuğun yaş1 ile pozitif ilişki göstermiştir. Tablo 1'de görülebileceği gibi, Türkiye verileriyle elde edilen bulgularda ÇBÇÖ 2’li faktör yapısıyla Amerika'da geliştirilen asıl ölçekten ayrılmaktadır (Solomon ve George, 2011). Fakat mevcut çalışmamızda anne çaresizliği ve anne-çocuk korkusu alt ölçeklerinin tek bir alt ölçek olarak karşımıza çıkması şaşırtıcı değildir. Çünkü orijinal ölçek çalışmasında (Solomon ve George, 2011) da bu iki alt ölçek yüksek oranda korelasyon göstermektedir $(\mathrm{r}=.58, \mathrm{p}<.01)$. Ayrıca ölçek maddeleri incelendiğinde de bakım veren çocuk alt ölçeğinin çocuğun durumuna odaklanarak ayrıştığı görülmektedir. Solomon ve George (2011)'da anne çaresizliği alt ölçeğinin olumsuz bakım vermeyi ve bakım sağlamada kişinin yaşadığı sorunları kapsadığına dikkat çekmiştir.

ÇBÇÖ'nün yordayıcı geçerlik yapısı incelendiğinde bulgularımız büyük oranda asıl ölçek çalışmasındaki (Solomon ve George, 2011) bulgulara parelel çıkmıştır. Annenin depresyonu ve kaygısı ile olumlu ilişki gösteren ÇBÇÖ'de anne çaresizliği ve anne-çocuk korkusu alt ölçeğinin belirleyici olduğu saptanmıştır. Diğer bir deyişle, annenin yaşadığı psikolojik zorluklarla çocuk bakımında yaşadığı zorluklar paralellik göstermiştir. Ayrıca, anne çaresizliği ve anne-çocuk korkusu alt ölçeği çocuğun davranış sorunlarıyla pozitif ilişki göstermiştir. Bakım veren olarak çocuk alt ölçeği ise sadece içselleştirme davranışı ile ilişkili bulunmuştur. Solomon ve George (2011)'un "melek çocuk” tanımına uyabilecek çocukların davranış özelliklerinin bu alt ölçekte kapsandığına işaret etmektedir. Bu çocuklar içe kapanık ve karamsar halleriyle betimlenmektedirler.

Özetle, araştırma bulgularımız ölçeğin Türkiye örnekleminde 1-3 yaş arası çocuk sahibi ve görece daha düşük sosyoekonomik düzeydeki annelerde geçerli ve güvenilir olduğuna işaret etmektedir. Aynı zamanda ölçeğin asıl ölçek geliştirme çalışmasındaki (Solomon ve George, 2011) gibi çocuk bakım çaresizliği alt ölçeklerinin anne ve çocuk psikolojik sağlık değişkenleriyle ilişki göstermesi bulgularımızın alandaki müdahale programlarına 1şık tutması açısından önemlidir. Ancak çalışmamız bazı kısıtlılıklar da 
barındırmaktadır. Öncelikle düşük iç güvenirlik ve sınırlı yordayıcı geçerlik özellikleri nedeniyle yeni çalışmalarla bakım veren çocuk alt ölçeği dikkatle incelenmeli ve değerlendirilmelidir. Ölçek farklı yaş gruplarında çocukları olan, diğer sosyoekeonomik düzeyden gelen annelerde ve çocuklara bakım sağlayan diğer kişilerle de sınanmalıdır. Ayrıca, çocuk bakımında çaresizliğin, hem bakım sağlayan kişilerin hem de çocukların bireysel farklılıklarıyla nasıl değiştiği dikkate alınmalıdır. Genel hatlarıyla ölçek, annelerin ve ebeveynlerin çocuk bakımında yaşadıkları zorluklara odaklanan araştırmalarda kullanılarak, annelerin ve diğer bakım sağlayan kişilerin çaresizliklerinin tespitinde faydalı olabilir. Buna ek olarak, ölçek ebeveynlerin erken çocukluk döneminde yaşadıkları sorunların giderilmesini, çaresizliklerinin azaltılmasını ve daha olumlu ebeveynlik özellikleri kazandırmayı hedefleyen müdahale programlarının geliştirilmesine katkı sağlayacaktır.

Tablo 1

Çocuk Bakımında Çaresizlik Ölçeği Maddeleri ve Faktör Yükleri

\begin{tabular}{|c|c|c|c|}
\hline \multicolumn{2}{|c|}{ Çocuk Bakımında Çaresizlik Ölçeği Maddeleri } & \multicolumn{2}{|c|}{$\begin{array}{l}\text { Alt Ölçek Faktör } \\
\text { Yükleri }\end{array}$} \\
\hline & & $\mathrm{Mh}$ & $\mathrm{Cc}$ \\
\hline 1. & Çocuğumla birlikteyken kendimi sık sık kontrolü kaybetmiş gibi hissederim. & .28 & .03 \\
\hline 2. & Çocuğum diğer insanlara ilgi gösterir ve onları önemser. & -.07 & .45 \\
\hline 3. & Çocuğumdan korkarım. & .26 & .06 \\
\hline 4. & Çocuğum bana vurur, beni tekmeler ya da isırır. & .26 & .02 \\
\hline 5. & Genellikle çocuğumu terbiye etmek için yapabileceğim bir şey olmadığını düşünürüm. & .25 & -.03 \\
\hline 6. & Çocuğum diğer insanları nasıl rahat ettireceğini bilir. & .01 & .44 \\
\hline 7. & Çocuğumla birlikteyken sıklıkla çocuğumun kontrolden çıktığını hissederim. & .28 & .02 \\
\hline 8. & Çocuğumun çok iyi rol yaptığını düşünüyorum. & .23 & .13 \\
\hline 9. & Çocuğum başkalarının duygu ve ihtiyaçlarına karşı çok duyarlıdır. & -.02 & .47 \\
\hline 10. & Bir anne olarak kendimi başarısız hissediyorum. & .27 & .06 \\
\hline 11. & Çocuğum ailenin maskarası ya da komedyeni olmaktan hoşlanır. & .06 & .37 \\
\hline 12. & Çocuğumu gereğinden daha sert bir şekilde cezalandırdığımı düşünüyorum. & 29 & .06 \\
\hline 13. & Çocuğum sakinleştirilemeyecek kadar üzgün ya da sıkıntılı olur. & .31 & -.08 \\
\hline 14. & Çocuğum benden ayrıldığı zaman kendini kaybeder. & .24 & -.08 \\
\hline 15. & Çocuğum bazen benden korkuyormuş gibi davranır. & .28 & .04 \\
\hline 16. & Çocuğumla birlikte onu mutlu eden şeyler yapmaktan keyif alırım.* & & \\
\hline 17. & Çocuğum sürekli diğer insanları güldürmeye çalışır. & .05 & .40 \\
\hline 18. & $\begin{array}{l}\text { Şu andaki durumumun değişmesi gerektiğinin farkındayım, ama bunun için hiçbir şey } \\
\text { yapamayacak kadar çaresizim. }\end{array}$ & .31 & -.07 \\
\hline 19. & Kendimi güvenilir biri olarak tarif edebilirim. * & & \\
\hline 20. & Hayatımın karmakarışık ve kontrol edilemez olduğunu hissediyorum. & .30 & -.05 \\
\hline 21. & Çocuğumla birlikteyken nadiren sıkılırım.* & & \\
\hline 22. & Kendimden, olduğum gibi memnunum.* & & \\
\hline 23. & Davranışlarım hakkında nadiren suçlu hissederim.* & & \\
\hline 24. & Kendimi başkalarına kolayca ifade edebilirim.* & & \\
\hline 25. & Kendimi kolayca başkalarına açabilirim.* & & \\
\hline 26. & Çocuğum hakkında başkalarıyla sık sık konuşurum.* & & \\
\hline
\end{tabular}

Not. *Dolgu maddeleri. 